\title{
Metals in sediments: bioavailability and toxicity in a tropical reservoir used for public water supply
}

\author{
Sheila Cardoso-Silva • Daniel Clemente Vieira Rego Da Silva • Fernanda Lage • \\ Teresa Cristina Brazil de Paiva • Viviane Moschini-Carlos • André Henrique Rosa • \\ Marcelo Pompêo
}

Received: 11 March 2015 / Accepted: 19 November 2015 / Published online: 27 April 2016

(C) Springer International Publishing Switzerland 2016

\begin{abstract}
Sediments may be a repository of contaminants in freshwater ecosystems. One way to assess the quality of this compartment, in terms of potentially bioavailable metals, is by the analysis of acid-volatile sulfide (AVS) and simultaneously extracted metals (SEM). In order to investigate the bioavailability, toxicity, and compartmentalization of different metals $(\mathrm{Cd}$, $\mathrm{Cr}, \mathrm{Cu}, \mathrm{Ni}, \mathrm{Pb}, \mathrm{Zn}$ ), sampling of surface sediments was performed at nine stations along the Paiva Castro reservoir (São Paulo, Brazil). The metals were analyzed using atomic absorption spectroscopy. Sediment organic matter $(\mathrm{OM})$, organic carbon $(\mathrm{OC})$, and grain size were also measured. The parameters $\mathrm{pH}, \mathrm{E}_{\mathrm{H}}$, temperature, and dissolved oxygen were determined at the sediment-water interface. Chronic and acute toxicological tests were performed with sediments from the area where water was extracted for the public water supply. Low levels of OM, associated with loss of stratification in the water column, explained the relatively low AVS values. The molar ratio $\sum[\mathrm{SEM}]-[\mathrm{AVS}] / f \mathrm{OC}$ was less than $130 \mathrm{mmol} / \mathrm{kg}^{-1}$ for all the sampling stations, indicating that the metals were not bioavailable. With the
\end{abstract}

\footnotetext{
S. Cardoso-Silva $(\bowtie) \cdot$ V. Moschini-Carlos $\cdot$ A. H. Rosa Environmental Sciences Program, UNESP, Sorocaba campus, Sorocaba, SP, Brazil

e-mail: sheilacardoso@usp.br

D. C. V. R. Da Silva · F. Lage · M. Pompêo

Ecology Department, Institute of Biosciences, University of São Paulo, São Paulo, SP, Brazil

T. C. B. de Paiva

University of São Paulo, Lorena, SP, Brazil
}

exception of $\mathrm{Cd}$, metal levels were in accordance with background concentrations and the threshold effect level (TEL) established by the Canadian Council of Ministers of the Environment. The ecotoxicological tests confirmed the absence of toxic effects to biota. Application of principal component analysis indicated the presence of four compartments along the reservoir: (1) a riverine zone, potentially threatened by contamination with $\mathrm{Cd}$; (2) an intermediate zone; (3) a limnic area; and (4) the area where water was taken for the public water supply.

Keywords Metal · Sediment · Contamination · Toxicity · Spatial heterogeneity

\section{Introduction}

Although the analysis of metal concentrations in sediments is important, this alone is unable to provide an accurate prediction of the existence of environmental impacts in a given region (Prica et al. 2010). It is important to examine the bioavailability of potential contaminants, because high concentrations of metals in sediments do not necessarily result in immediate damage to biota.

One way to assess the bioavailability of metals is by a technique first described by Di Toro et al. (1990) and now widely used: the acid-volatile sulfide (AVS) and simultaneously extracted metals (SEM) procedure. The technique is based on equilibrium partitioning theory $(\mathrm{EqP})$, which predicts that in sediments where there is an 
excess of AVS, relative to the molar sum concentration of SEM, there will not be any release of the contaminants into the pore water (Garcia et al. 2011). This is because metals form weakly soluble sulfide compounds, which therefore mitigates the toxic effects on the benthic community (USEPA 2005; Campana et al. 2009; Simpson et al. 2012; Younis et al. 2014). On the other hand, when the relationship is reversed, metals may be bioavailable and toxicity to biota is likely to occur.

The AVS fraction is considered one of the most important metal binding phases in the sediments of anoxic environments (Di Toro et al. 1990; Yin and Fan 2011), controlling metal speciation, bioavailability, and toxicity. Sulfides are formed in anaerobic environments by sulfate reduction by bacteria in the presence of organic substances. In the sediments of aquatic ecosystems, most sulfides are complexed to Fe (De Jonge et al. 2009). When a divalent metal $\left(\mathrm{M}^{2+}\right)$ enters the aquatic environment, it causes the dissolution of iron sulfide (FeS) and then becomes associated with the sulfur, forming a slightly soluble metal complex according to the reaction: $\mathrm{M}^{2+}+\mathrm{FeS}_{(\mathrm{s})} \rightarrow \mathrm{MS}_{(\mathrm{s})}+\mathrm{Fe}^{2+}$.

The SEM method generally includes only five divalent metals: cadmium, copper, lead, nickel, and zinc (Allen et al. 1991; Prica et al. 2008). However, silver, chromium, and mercury are also often included in environmental studies (Silvério et al. 2005; Araújo et al. 2006a; Nizoli and Luiz-Silva 2012; Velimirović et al. 2011). These elements are considered the main metals responsible for sediment toxicity (USEPA). Chromium, in particular, does not form complexes with metal sulfides, but its toxicity is reduced by the presence of AVS; under such conditions, $\mathrm{Cr}(\mathrm{IV})$, which is highly toxic, is reduced to Cr(III), a less stable form (USEPA 2005).

Equilibrium partitioning theory has been used to develop sediment quality guidelines (SQGs) able to infer the bioavailability of metals. According to the SQGs, molar ratios between simultaneously extracted metals (SEM) and acid-volatile sulfide (AVS) can indicate states where toxicity is unlikely, uncertain, or likely to occur. In order to normalize these models, the use of the organic matter, an important metal binding phase, can also be applied (USEPA 2005).

There are also SQGs that are based empirically on the concentrations of individual chemical contaminants and their observed biological effects (Mozeto et al. 2006), such as the SQGs model PEL (probable effect level) and TEL (threshold effect level). In this model, for each contaminant, there is a range of values, whereby above a certain concentration (PEL), a toxic effect is likely to occur, while effects are unlikely at concentrations below the TEL, a value also known as interim sediment quality guideline (ISQG). At values between the TEL/ISQG and the PEL, effects can possibly occur (CCME 1999).

Both models (SEM/AVS and ISQG/PEL) have been validated in the field and in the laboratory (Yin and Fan 2011) and are widely used in assessing the quality of sediments (Hübner et al. 2009). They provide important tools to evaluate contamination levels and contaminant bioavailability. However, the use of these models alone can be questioned, because although bioavailability may be identified, it might not necessarily lead to toxicity (Lee et al. 2000). Ecological and physiological differences modify the extent to which organisms are exposed to metals (Lee et al. 2000), so either the presence or absence of toxic effects could be observed. Thus, though not essential, toxicity tests are recommended to complement the application of SQGs (Pompêo et al. 2013).

In addition to the bioavailable metal analysis in an aquatic ecosystem, it is also important to assess the spatial distribution for these contaminants in order to define the worst affected areas. This information is important to better understand the ecosystem dynamics and functioning as well as to help establish water resources monitoring and management programs. This is important because different degrees of contamination can lead to different ways of operating and treating the system. Studies of contaminants spatial distribution in aquatic ecosystems also help define priority areas to implement control measures.

This study examines the bioavailability and toxicity of metals in sediments of Paiva Castro reservoir, a reservoir used for public water supply. Despite the importance of the region, with the exception of few scientific researches, there is little scientific information available regarding this reservoir, particularly for sediments. It is a known fact that the area is contaminated by metals, particularly copper, as demonstrated by Cardoso-Silva et al. (2016) and Beghelli et al. (2016 accepted for publication). The first authors found copper levels exceeding the background up to fourfold $(97.0 \mathrm{mg} / \mathrm{kg})$. Despite these data, there is no information to confirm if metals are being released into the water column, becoming bioavailable or causing toxicity to biota. The heterogeneity in the spatial distributions of the potential contaminants was also analyzed in order to obtain information important for reservoir management procedures. 


\section{Materials and methods}

Study area

The Cantareira system is the main source of drinking water for the metropolitan region of São Paulo. It has a flow of $33 \mathrm{~m}^{3} \mathrm{~s}^{-1}$ (Whately and Cunha 2007), an extent of $48 \mathrm{~km}$, and is composed of five reservoirs, the Paiva Castro, Atibainha, Cachoeira, Jaguari, and Jacareí, connected by artificial underground tunnels, canals, and pumps (Whately and Cunha 2007). The Paiva Castro reservoir, the last of this artificial cascade system, is located in the upper Tietê hydrographic basin and is formed by a dam on the Juquery River. It has an altitude of $745 \mathrm{~m}$, a drainage area of $314 \mathrm{~km}^{2}$, and a mean flow of $4.4 \mathrm{~m}^{3} \mathrm{~s}^{-1}$. Effluents from the sewage treatment station of Mairiporã city are released upstream of the Paiva Castro. Substantial population growth (Whately and Cunha, 2007) has been associated with increased nutrient inputs into this reservoir (Giatti 2000; Silva 2002). In order to control algae blooms, there are regular applications of algicides such as copper sulfate and hydrogen peroxide. This practice is responsible for copper levels above background values (Cardoso-Silva et al. 2016).
Sampling

Sampling in the Paiva Castro reservoir was performed on July 13, 2010, in the dry season, in order to analyze metals and other variables in the superficial sediments. Nine sites were used; seven along the main axis of the reservoir and two in a lateral arm, where water was extracted for public water supply (Fig. 1). The sampling sites were georeferenced with a GPS (Model 72, Garmin).

At each site, the depth was first determined, after which an Ambühl and Bührer sampler was deployed (Ambühl and Bührer 1975). Firstly, in situ measurements were made of the following variables: redox potential $\left(\mathrm{E}_{\mathrm{H}}\right)$ (Digimed Model DMP-CP1 electrode with Gehaka Model PG1400 base); $\mathrm{pH}$ and temperature (T) in the first centimeter of the sediment, and dissolved oxygen (DO) in the top $5 \mathrm{~cm}$ below the sediment-water interface (YSI 556 MPS multiparameter probe). The first $3 \mathrm{~cm}$ of the sediment was then sampled and stored prior to AVS and SEM analyses (Allen et al. 1991, 1993). The sampler was deployed a second time and the first $3 \mathrm{~cm}$ of the sediment column were removed for grain size and organic matter analyses. The sediments were transferred to sealed plastic bags and stored in

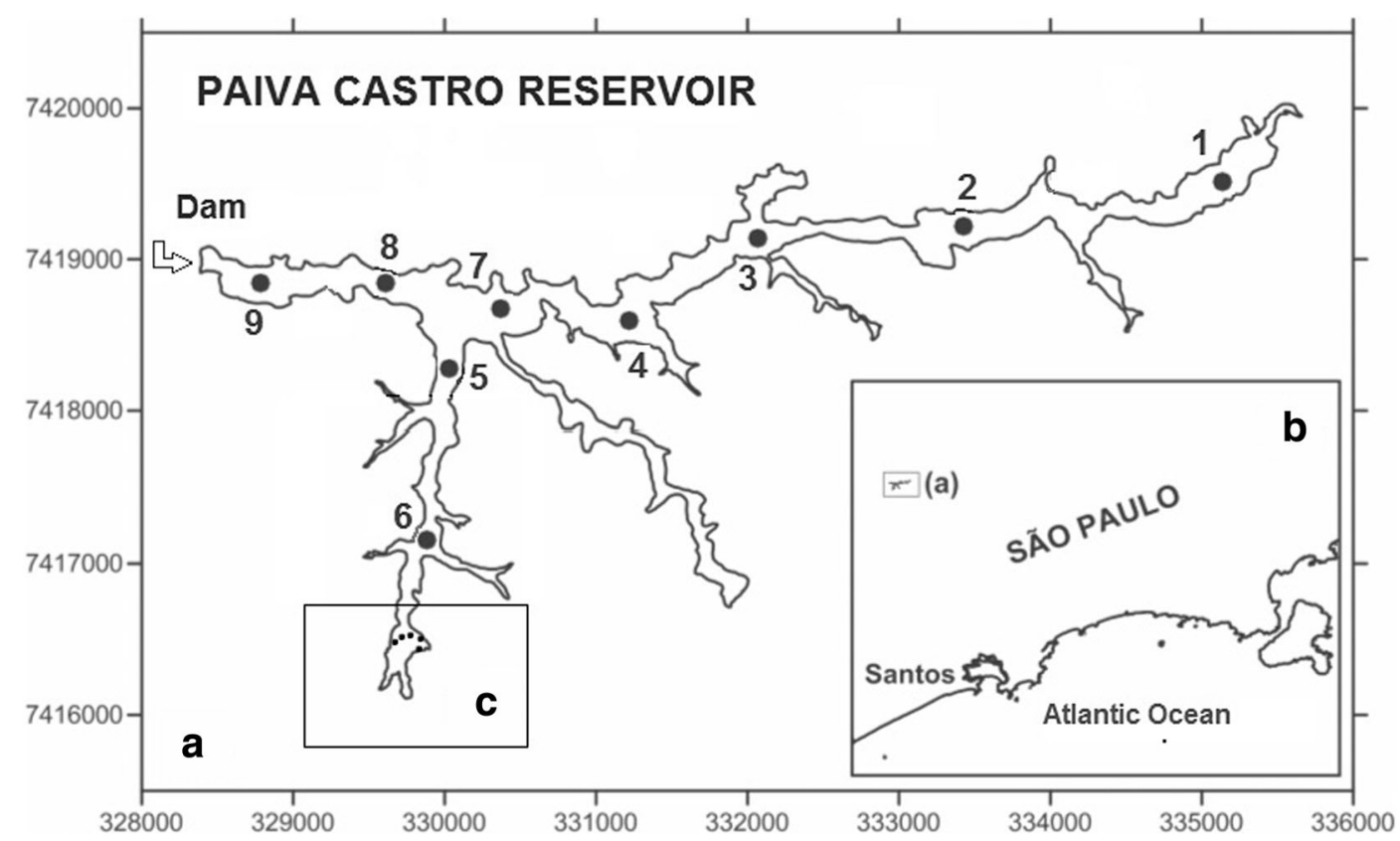

Fig. 1 Paiva Castro reservoir: a sediment sampling stations; b geographic location (São Paulo, Brazil); and c area with sampling stations for toxicity tests. Sampling stations were georeferenced according to the UTM coordinate system (datum SAD69 and central meridian $45^{\circ}$ ) 
thermal bags, until analyzed in the laboratory. SEM/ AVS analysis was carried out within 1 week after sampling, as recommended by Di Toro et al. (1991). At sampling stations 2, 6, and 9, the water column was analyzed to determine whether it was stratified. The variables used for this purpose were $\mathrm{pH}$, electrical conductivity (EC), T, and DO, measured with a multiparameter probe (YSI $556 \mathrm{MPS}$ ).

\section{Laboratory analysis}

Sample extraction and measurement of AVS and SEM were performed as described by Allen et al. (1991). Analytical grade reagents were used (obtained from Merck and Sigma-Aldrich). Samples were stored at $4{ }^{\circ} \mathrm{C}$ before analysis (using three replicates) of the metals zinc, copper, chromium, nickel, cadmium, lead, and manganese by atomic absorption spectrometry (AAS). Sulfide was determined spectrophotometrically with Hach test kits (sulfide 1, cat. $\mathrm{n}^{\circ}$ 1816-32 3; sulfide, cat. $\mathrm{n}^{\circ}$ 1817-33). AVS and SEM concentrations were expressed as milligram per kilogram of dry sediment.

Organic matter (OM) was determined by ignition Meguro (2000). Organic carbon was inferred using the equation $\mathrm{OM}=\% \mathrm{C} \times 1.7$, which assumes that the organic matter contains $58 \%$ carbon Meguro (2000). Grain size analysis employed the Atterberg system and the beaker method, proposed by Piper (1947) and modified by Meguro (2000).

Data analysis

Three SQGs were used: (1) the equilibrium partitioning approach (USEPA 2005); (2) the empirical SQG from CCME (1999), ISQG (Interim Sediment Quality Guideline), and PEL (Probable Effect Level); (3) background values established for the upper Tietê basin $(\mathrm{Cd})$ (Nascimento and Mozeto 2008) and for the Paiva Castro reservoir ( $\mathrm{Cr}, \mathrm{Cu}, \mathrm{Ni}, \mathrm{Pb}, \mathrm{Zn}$, and $\mathrm{Mn}$ ) Cardoso-Silva et al. (2016).

The data were analyzed using basic descriptive statistics and the PCA (Principal Component Analysis) multivariate statistical technique based on a correlation matrix (Legendre and Legendre 1998). In the PCA procedure, centroid representation was performed using cluster analysis by the method of complete linkage and Euclidean distance, from the values obtained by the PCA scores 1 and 2. The centroid was calculated as the mean values of the scores of axes 1 and 2 corresponding to each group observed in the cluster analysis. Data analysis was performed using the PAST Hammer et al. (2001) and Statistica 7.0 software packages.

\section{Toxicity tests}

Once bioavailability analysis was performed, it was necessary to confirm if toxicity was in fact occurring. In such way, other sample collection was executed in the dry season in May 2011. Toxicity tests were performed using sediment from five locations in the reservoir where water was extracted for public supply, at coordinates: (1) 0329445, 7414987; (2) 0329357, 7415202; (3) 0329413, 7415264; (4) 0329415, 7415110; and (5) 0329412, 7415356. At each point the sediments were obtained (in triplicate) with an Ekman sampler $\left(625 \mathrm{~cm}^{2}\right)$. As soon as possible, the samples were preserved according to the ABNT (2007) protocol. The tests with sediments used the organisms Daphnia similis (acute test) and Chironomus xanthus (chronic test) (ABNT 2009; Fonseca 1997). In the case of the sediments, measurements were also made of $\mathrm{pH}$ (YSI 63/ 100 FT probe) and OM levels Meguro (2000). The tests included controls, with the same number of replicates as the samples, using the water in which the organisms were cultivated in the laboratory.

Statistically significant differences between the sampling stations, in terms of the results of the ecotoxicological tests, were evaluated using TOXSTAT v. 3.4 software. In the chronic sediment toxicity evaluation, the treatments were compared to the control using the $\chi^{2}$ normality test and ANOVA, or alternatively Dunnett's test or Steel's many-one rank test, with the KruskalWallis test, when normality and homogeneity were not observed. For the acute evaluation using sediment, Fisher's exact test was used. The level of significance adopted was $p<0.05$.

\section{Results}

The depth along the Paiva Castro reservoir increased from upstream to downstream, as expected, ranging from 1 to $18 \mathrm{~m}$. In the surface water, redox potential values associated with DO (Table 1) indicated the presence of oxidative processes. The highest value for $E_{H}$ was found upstream at Site 1 and the lowest was downstream at Site 7 . The lowest DO values were also 
Table 1 Descriptive statistics for variables of the superficial sediments of the Paiva Castro reservoir: mean, standard deviation (SD), minimum (Min), maximum (Max), and coefficient of variation (CV\%)

\begin{tabular}{|c|c|c|c|c|c|c|c|}
\hline & Mean & $\mathrm{SD}$ & Min & Sample & Max & Sample & $\mathrm{CV} \%$ \\
\hline Depth (m) & 10.3 & 5.5 & 0.9 & 1 & 18.1 & 9 & 53 \\
\hline Temperature $\left({ }^{\circ} \mathrm{C}\right)$ & 17.9 & 0.4 & 17.6 & $7 / 9$ & 18.6 & 1 & 1.9 \\
\hline $\mathrm{E}_{\mathrm{H}}(\mathrm{mV})$ & 68.5 & 32.2 & 17 & 7 & 135.0 & 1 & 46.0 \\
\hline $\mathrm{pH}$ & 6.7 & 0.5 & 6.5 & 6 & 8.0 & 1 & 6.9 \\
\hline Dissolved oxygen $\left(\mathrm{mg} \mathrm{L}^{-1}\right)$ & 8.9 & 1.3 & 6.3 & 8 & 10.0 & 3 & 16.1 \\
\hline Organic matter $(\%)$ & 4.9 & 2.7 & 2.5 & 8 & 10.9 & 6 & 0.6 \\
\hline Silt (\%) & 59.6 & 18.0 & 30.5 & 1 & 85.0 & 3 & 0.3 \\
\hline Clay $(\%)$ & 27.8 & 15.1 & 7.1 & 1 & 46.7 & 5 & 0.5 \\
\hline Sand $(\%)$ & 12.6 & 23.3 & 0.2 & 4 & 62.4 & 1 & 1.9 \\
\hline $\mathrm{Cd}\left(\mathrm{mg} \mathrm{kg}^{-1}\right)$ & 0.3 & 0.1 & 0.1 & 8 & 0.4 & 1 & 40.6 \\
\hline $\mathrm{Cu}\left(\mathrm{mg} \mathrm{kg}^{-1}\right)$ & 3.9 & 6.6 & 3.5 & 3 & 21.0 & 4 & 174.1 \\
\hline $\mathrm{Ni}\left(\mathrm{mg} \mathrm{kg}^{-1}\right)$ & 1.4 & 1.6 & 0.5 & 5 & 4.5 & 9 & 111.7 \\
\hline $\mathrm{Pb}\left(\mathrm{mg} \mathrm{kg}^{-1}\right)$ & 13.5 & 6.6 & 3.8 & 5 & 20.5 & 1 & 48.9 \\
\hline $\mathrm{Zn}\left(\mathrm{mg} \mathrm{kg}^{-1}\right)$ & 12.9 & 7.7 & 7.5 & 7 & 30.0 & 8 & 59.4 \\
\hline $\operatorname{Mn}\left(\mathrm{mg} \mathrm{kg}^{-1}\right)$ & 241.7 & 224.8 & 107.1 & 8 & 691.0 & 1 & 93.0 \\
\hline $\operatorname{AVS}\left(\mathrm{mg} \mathrm{kg}^{-1}\right)$ & 14.8 & 6.5 & 9.3 & 7 & 22.3 & 6 & 44.2 \\
\hline
\end{tabular}

observed in the downstream region nearer the dam, at Sites 7-9. The pH along the Paiva Castro reservoir mostly ranged between neutral and acidic and was only basic at Site 1 . The coefficient of variation (CV) was low for the variables temperature, $\mathrm{pH}$, and DO. In general, $\mathrm{CV}$ values below $20 \%$ are considered to reflect little variation or even an absence of variation (Griethuysen et al. 2006). The temperature, pH, electrical conductivity, and dissolved oxygen measurements indicated that the water column was not stratified at the three sites evaluated (Fig. 2).

In the superficial sediment, the organic matter percentage did not exceed $12 \%$ at any of the sites (Table 1). Higher sand contents were found for Site 1, in the fluvial region, and for Site 6, in the area used for extraction of water for public supply (Table 1). In the case of AVS, the value for Site 3 was below the detection limit. The highest concentrations of $\mathrm{Cd}, \mathrm{Pb}$, and $\mathrm{Mn}$ were found
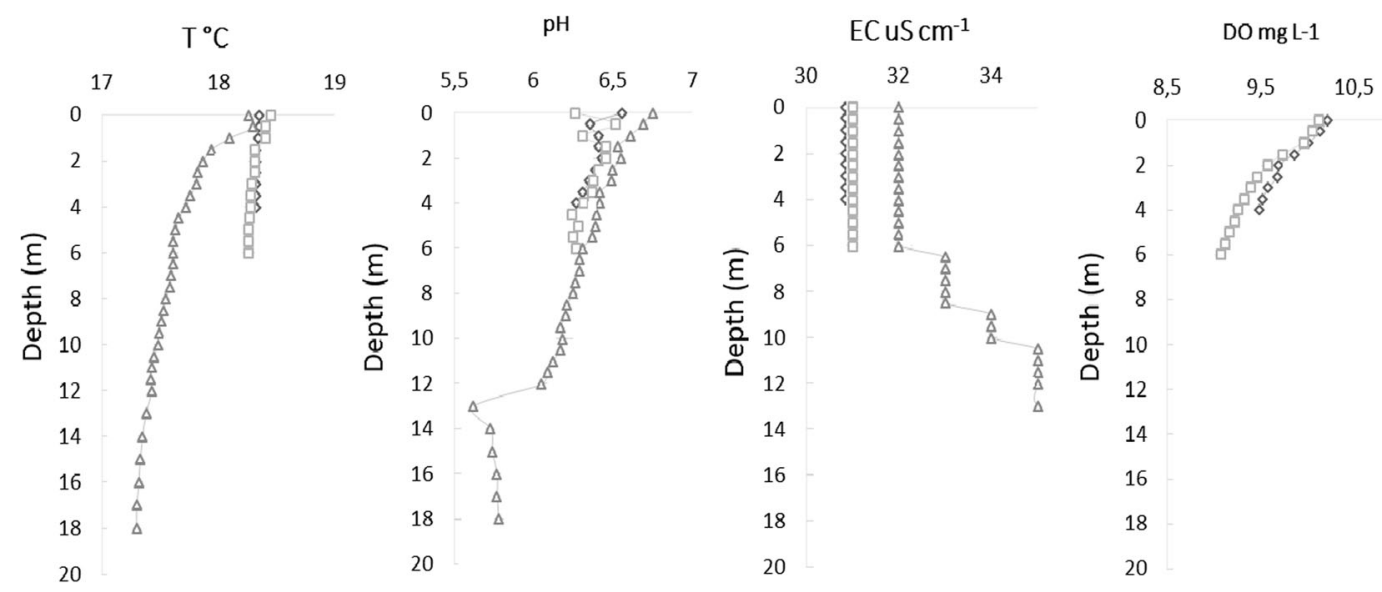

P2 $\triangle \quad P 3$

P9 $\theta$

Fig. 2 Profiles of the variables temperature $\left(\mathrm{T},{ }^{\circ} \mathrm{C}\right), \mathrm{pH}$, electrical conductivity (EC, $\mu \mathrm{S} \mathrm{cm}^{-1}$ ), and dissolved oxygen (DO, $\mathrm{m} \mathrm{L} \mathrm{L}^{-1}$ )

in three sampling stations in the water column of the Paiva Castro reservoir 
in the upstream area, while the highest concentrations of $\mathrm{Ni}$ and $\mathrm{Zn}$ were measured in the downstream area, and the highest concentration of $\mathrm{Cu}$ was at Site 4 (Fig. 3; Table 1). For all the metals analyzed, the CV values
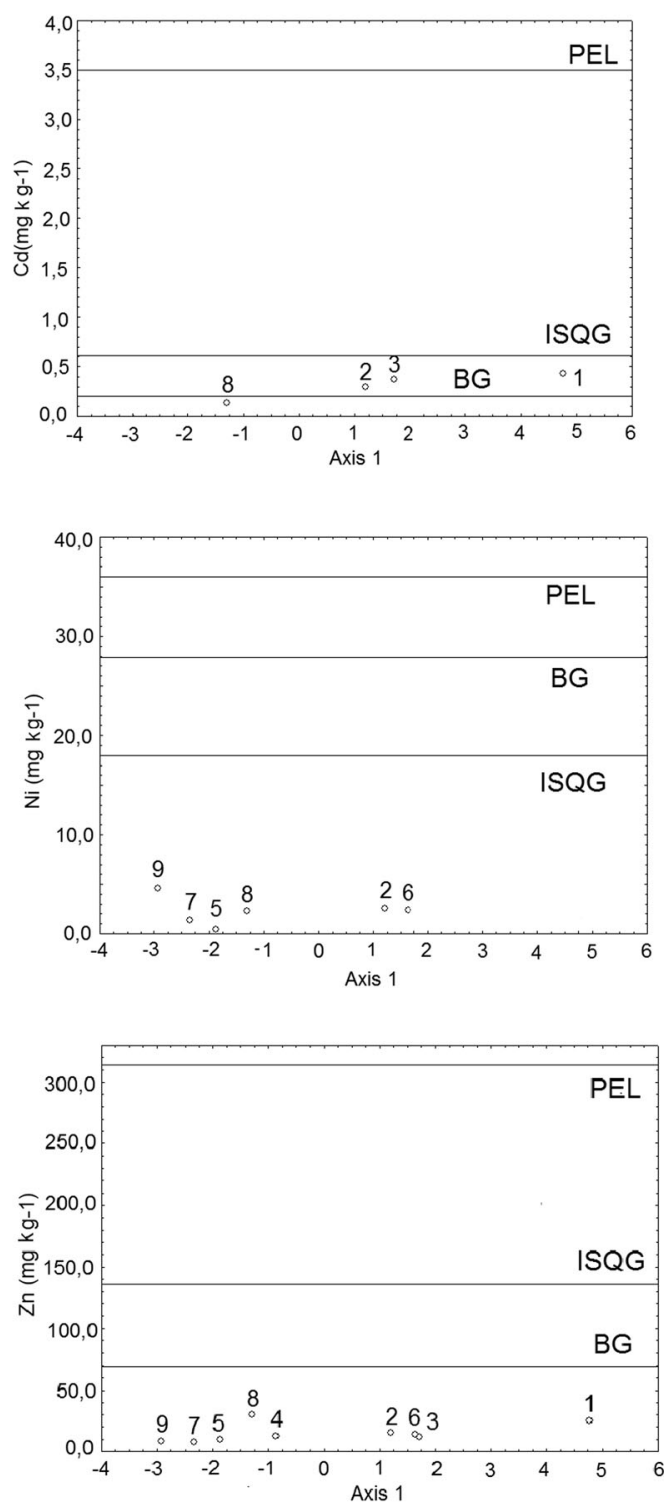

Fig. 3 Concentrations of cadmium, copper, nickel, manganese, lead, and zinc in the Paiva Castro sediments. The background were greater than $40 \%$ (Table 1). Levels of chromium were below the detection limit for all sites. The concentrations of the metals did not exceed ISQG limits and were below background levels.
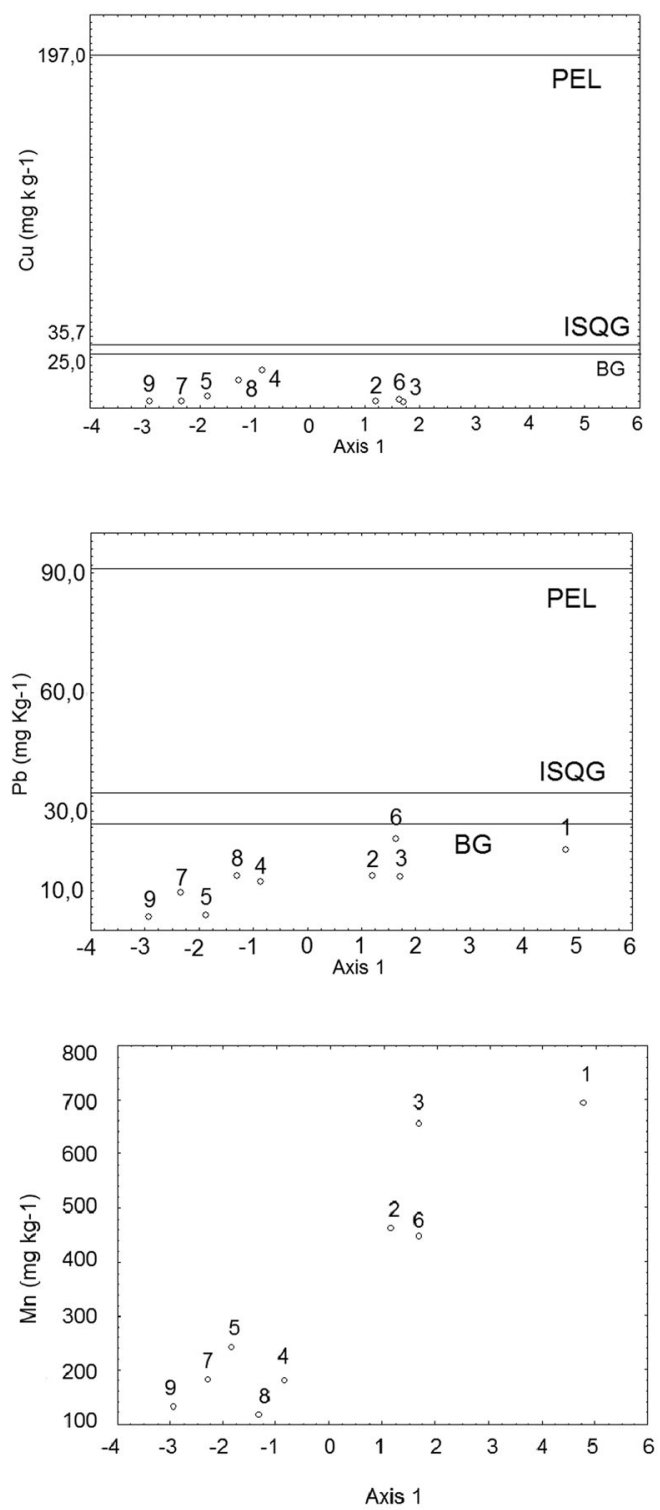

(BG), ISQG, and PEL values are indicated. The sampling stations are arranged according to PCA axis 1 
Metals levels were low comparing to the background. In Fig. 3, sampling stations are arranged according to PCA axis 1 , being this way organized in space according to similarity.

Cadmium levels were above background in the upstream area (samples from Sites 1-3). However, according to the equilibrium partitioning approach, toxicity was considered unlikely to occur at these sites. For all other sites, the relations based on equilibrium partitioning, $\sum[\mathrm{SEM}]-[\mathrm{AVS}] / f \mathrm{OC}$ and $\sum[\mathrm{SEM}]-[\mathrm{AVS}]$, indicated that toxicity was unlikely to occur (Table 2).

The acute and chronic toxicity tests data indicated non-toxicity to Daphnia similis and Ceriodaphnia dubia, respectively (Table 3). The $\mathrm{pH}$ was higher than pH 6 at all sites (pH 6.4), which was favorable for metal immobilization in the sediment.

\section{Discussion}

Toxicity and bioavailability

According to the models and procedures used in this research, the metal concentrations measured along a longitudinal gradient at the Paiva Castro reservoir did not indicate potential toxicity or bioavailability. Data

Table 2 Sediment quality guidelines based on the equilibrium partitioning approach (USEPA 2005). Values expressed in millimoles per kilogram of dry sediment

\begin{tabular}{|c|c|c|c|}
\hline \multicolumn{2}{|c|}{ Sampling site } & $\sum_{f \mathrm{OS}}[\mathrm{SEM}]-[\mathrm{AVS}] /$ & $\sum[\mathrm{SEM}]-[\mathrm{AVS}]$ \\
\hline \multicolumn{2}{|l|}{1} & 7.76 & 0.2 \\
\hline \multicolumn{2}{|l|}{2} & 5.2 & 0.18 \\
\hline \multicolumn{2}{|l|}{3} & 9.21 & 0.3 \\
\hline \multicolumn{2}{|l|}{4} & 8.94 & 0.32 \\
\hline \multicolumn{2}{|l|}{5} & 1.78 & 0.03 \\
\hline \multicolumn{2}{|l|}{6} & 1.57 & 0.09 \\
\hline \multicolumn{2}{|l|}{7} & 4.49 & 0.1 \\
\hline \multicolumn{2}{|l|}{8} & 20.57 & 0.55 \\
\hline \multicolumn{2}{|l|}{9} & 1.59 & 0.04 \\
\hline \multicolumn{2}{|l|}{ Mean } & 6.79 & 0.2 \\
\hline \multirow[t]{3}{*}{ Toxicity } & Unlikely to occur & $<130$ & $<1.7$ \\
\hline & Uncertain to occur & $130<x>3000$ & $1.7<x>120$ \\
\hline & Likely to occur & $>3000$ & $>120$ \\
\hline
\end{tabular}

Table 3 Toxicity tests for sediments, using Daphnia similis (acute test) and Chironomus xanthus (chronic test). The sediment was from the region of the Paiva Castro reservoir used for public water supply

\begin{tabular}{lll}
\hline & \multicolumn{2}{l}{ Sediment } \\
\cline { 2 - 3 } Sampling site & Acute test & Chronic test \\
\hline 1 & NT & NT \\
2 & NT & NT \\
3 & NT & NT \\
4 & NT & NT \\
5 & NT & NT \\
\hline
\end{tabular}

NT nontoxic, $T$ toxic

analysis suggested that a number of factors contributed to the immobilization of the metals in the sediments, such as $\mathrm{pH}$ and the levels of sulfide and organic matter.

The Paiva Castro sediments presented hydrogen sulfide characteristics, with sulfide concentrations above $34.1 \times 10^{-3} \mathrm{mg} \mathrm{L}^{-1}$ (Berner 1981) for all sampling sites $\left(0.15 \pm 0.07 \mathrm{mg} \mathrm{L}^{-1}\right)$, with the exception of Site 3 . In addition, the $\mathrm{E}_{\mathrm{H}}$ values were below $120 \mathrm{mV}$ (Bartlett 1999 apud De Jonge et al. 2012a) indicating favorable conditions for sulfide formation. Therefore, there was the potential for binding of metals by sulfide in the study area.

However, despite this potential formation of sulfide, the mean concentration of AVS $\left(15 \mathrm{mg} \mathrm{kg}^{-1}\right)$ was low, especially when compared to mean sulfide values found for other reservoirs located in the same watershed, such as the Guarapiranga reservoir, with $145 \mathrm{mg} \mathrm{kg}^{-1}$ (Pompêo et al. 2013), and the Rio Grande reservoir in the Billings complex of reservoirs, with $422 \mathrm{mg} \mathrm{kg}^{-1}$ (Mariani and Pompêo 2008), where sulfides play a key role in metal adsorption. The low AVS values for the Paiva Castro reservoir can be explained by two main factors: (1) low organic matter levels, which categorized Paiva Castro sediments as inorganic, and (2) oxygenation of the hypolimnion region due to destratification of the water column, which contributed to the instability of any sulfides formed.

In the case of the first factor, despite high population growth and increased nutrient inputs to this reservoir, the magnitude of the impact has not yet been reflected in high levels of organic matter. Considering the second factor, it is known that the dissolved oxygen in surface waters exerts a major influence on AVS concentrations (Griethuysen et al. 2006). Exposure of the sediment to 
dissolved oxygen results in oxidation of sulfides and the conversion of metals to forms that are more bioavailable (Simpson et al. 2012; De Jonge et al. 2012b). This process can be problematic in areas with high metal levels, because it can promote release of the contaminants into the water column. In the present case, however, metal levels were below the ISQG values, so adverse effects on biota were unlikely to occur.

Therefore, despite the potential immobilization of metals by sulfide, the presence of oxygen hindered AVS formation, especially at Site 3 , favoring the occurrence of other metal binding processes. For example, oxyhydroxides of iron $(\mathrm{FeOOH})$ and manganese $(\mathrm{MnOOH})$ are considered important metal binding phases that can reduce the mobility, bioavailability, and toxicity of metals (Huerta-Diaz et al. 1993; Chapman et al. 1999; De Jonge et al. 2009). Oxides of $\mathrm{Fe}$ and Mn play a key role in metal adsorption (Fang and Zhang 2005), especially in aerobic environments where the formation of sulfides is thermodynamically unstable (Simpson et al. 2012). Although oxyhydroxides and Fe levels were not analyzed in the present study, the present data suggested the importance of Mn as a metal binding phase, because the manganese concentrations had significant correlations with the concentrations of $\mathrm{Cd}$ and $\mathrm{Pb}$, as it can be seen in the PCA analysis (Table 4; Fig. 4a).

Fine-grained sediments with particles smaller than $63 \mu \mathrm{m}$ (silt and clay) play an important role in metal retention, because smaller grains provide a greater area available for metal binding (Förstner and Wittmann 1981; Luoma and Rainbow 2008). The importance of this component for metal immobilization was observed through the PCA results. Data from PCA shows the correlation between the variables clay and copper, for sampling sites in the dam area (Table 4, Fig. 4a).

In addition to iron and manganese oxyhydroxides and fine-grained sediments, organic matter also acts as a metal binding phase. Despite the low values for organic matter identified in this study, there was a correlation between lead and organic matter levels (Table 4, Fig. 4a). Similarly, the $\mathrm{pH}$ values found here supported the immobilization of the metals in the sediments. Under conditions where the $\mathrm{pH}$ is close to neutral, metal partitioning between the sediment particles and the pore water favors binding to the solid phase (Luoma and Rainbow, 2008). The $\mathrm{pH}$ values above $\mathrm{pH} 6$ indicated that the sediment particle surface possessed a residual negative charge, favoring the adsorption of metal ions
Table 4 Loads of two principal components for the variables introduced in the PCA analysis. Values higher than 0.500 are given in italics

\begin{tabular}{ccc}
\hline & Axis 1 & Axis 2 \\
\hline AVS & 0.01 & 0.83 \\
Depth (Z) & -0.91 & 0.07 \\
Temperature (T) & 0.73 & -0.12 \\
pH & 0.47 & 0.46 \\
Dissolved oxygen (DO) & 0.55 & -0.63 \\
E $_{\mathrm{H}}$ & 0.89 & -0.02 \\
$\mathrm{Cu}$ & -0.40 & -0.01 \\
$\mathrm{Ni}$ & -0.45 & 0.37 \\
$\mathrm{Zn}$ & 0.44 & 0.45 \\
$\mathrm{~Pb}$ & 0.81 & 0.24 \\
$\mathrm{Cd}$ & 0.79 & -0.25 \\
Mn & 0.92 & -0.27 \\
Silt & -0.23 & -0.81 \\
Clay & -0.93 & 0.13 \\
Sand & 0.79 & 0.54 \\
Organic matter & 0.33 & 0.03 \\
\hline & & \\
\hline & & \\
\hline
\end{tabular}

(Araújo et al. 2006b). This was corroborated by the positive correlations obtained between $\mathrm{pH}$ and the metals $\mathrm{Cd}, \mathrm{Zn}$, and $\mathrm{Pb}$ (Table 4, Fig. 4a).

Through the PCA, it was also possible to have other useful information about the processes governing sediment biogeochemistry in Paiva Castro sediments. The PCA component plots (Fig. 4a) indicated the influence of (axis 1) the variables clay, depth, $\mathrm{Mn}, \mathrm{E}_{\mathrm{H}}, \mathrm{Pb}$, and $\mathrm{Cd}$ and (axis 2) the variables AVS, silt, and DO (Fig. 4a; Table 4).

The variables $\mathrm{Pb}, \mathrm{Mn}$, and $\mathrm{Cd}$, positively correlated to axis 1, presented higher levels in the upstream area, closer to Mairiporã city. The $\mathrm{Pb}$ could have originated from natural variations because levels were below background. Cardoso-Silva et al. (2016) also did not find signs of contamination for this metal in the present time in the area. However, cadmium concentrations above background were indicative of anthropogenic contamination. Although there are no official records of industrial activities in the catchment area of the Paiva Castro reservoir, the watersheds of the Cantareira system sustain agricultural practices, which could be a source of pollutants. Several studies have reported the contamination of soil and/or sediment due to the use of mineral 
a

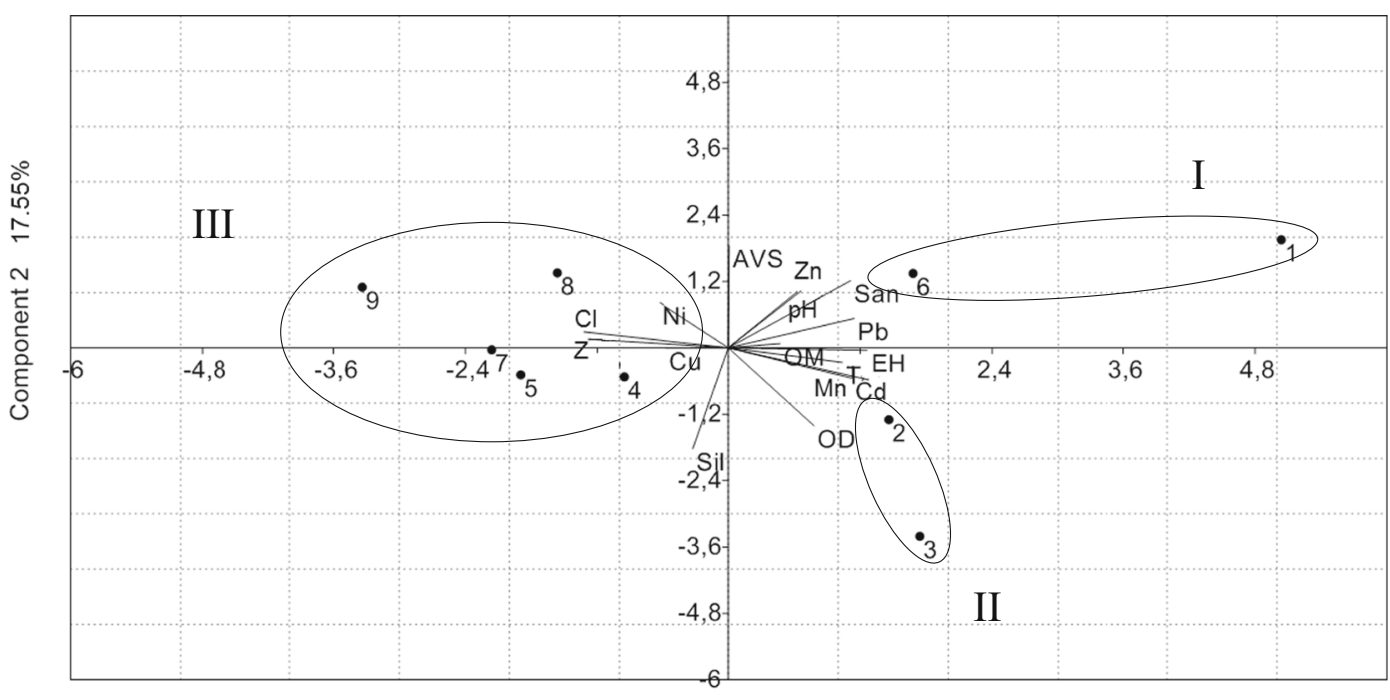

Component $143.87 \%$

b

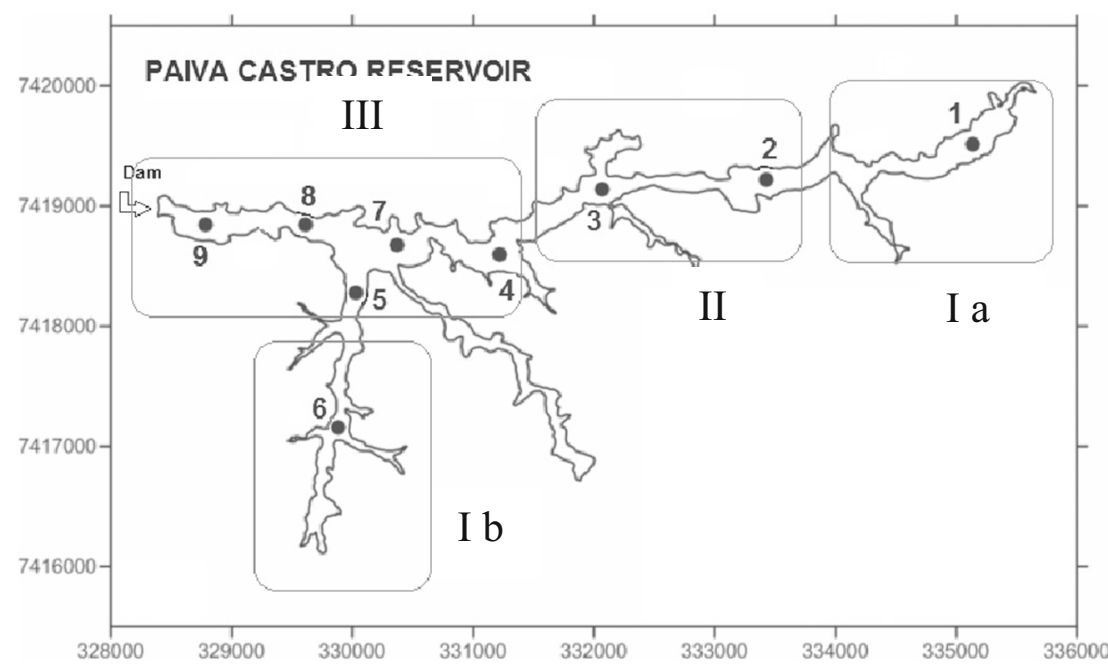

Fig. 4 a Principal component analysis of the correlation of measured variables for the superficial sediments of the Paiva Castro reservoir: $\mathrm{Ni}, \mathrm{Cu}, \mathrm{Mn}, \mathrm{Cd}, \mathrm{Pb}, \mathrm{Zn}$, clay $(\mathrm{Cl})$, silt (Sil), sand (Sd), dissolved oxygen (DO), organic matter (OM), acid-volatile sulfide (AVS), depth (Z), $\mathrm{E}_{\mathrm{H}}$, and $\mathrm{pH}$. b Four compartments of the Paiva
Castro reservoir identified from the PCA results. Compartment I was subdivided in $\mathrm{Ia}$ and $\mathrm{Ib}$ because although sampling sites 1 and 6 have chemical and physical similarities they are located in different areas in Paiva Castro reservoir phosphate fertilizer contaminated with cadmium (Mortvedt 1996; Jacob et al. 2013), including in Brazil (Bizarro et al. 2008). Manganese, in a previous study in the area (Cardoso-Silva et al. 2016), was also associated with human impacts because the highest levels for this metal were found near the area where effluents from the sewage treatment station of Mairiporã city are released, as in the present study. Manganese is commonly found in municipal wastewater, however, it is normally present at concentrations that do not pose any environmental risks (Vymazal and Svehla 2013).

The variables clay and depth, negatively correlated to axis 1 , were found in the deepest reservoir region, in the dam area, with high rates of sedimentation (He et al. 
2011) and small particle sizes, which explains the predominance of clay found in this region. Therefore, axis $1 \mathrm{can}$ be associated to anthropogenic impacts (chemical contamination) and to the structural dynamics of reservoirs. Whereas the second axis can be explained especially by AVS levels, positively correlated to axis 2, contrasting with the higher DO levels, negatively correlated to axis 2. As expected, these variables were inversely correlated.

Metals $\mathrm{Zn}$ and $\mathrm{Pb}$ were also significantly correlated (Table 4, Fig. 4a); this happened because these metals are usually found associated in nature, primarily in the form of lead sulfide (galena) (Allaby 2008). The observed relationship between metals $\mathrm{Ni}$ and $\mathrm{Cu}$ with clay in the dam area (Table 4, Fig. 4a) can be explained by the fact that $\mathrm{Ni}$ and $\mathrm{Cu}$ can form colloids and aggregates with clay and organic material (López et al. 2012).

Application of the empirical SQG models did not reveal any toxicity of the Paiva Castro sediments. The use of SQG models is recommended in areas where metal concentrations are not very high (Chapman et al. 1999; Hübner et al. 2009), as in the present case. Moreover, since there have been few studies that have investigated metal concentrations in the Paiva Castro reservoir, the SQG approach is useful as a tool for initial ecological risk assessment.

Metals levels were low comparing to the background. The method by which metals are removed from sediments can influence concentration (Luoma and Rainbow 2008). Background levels are in general based on total (hydrofluoric acid) and near total (concentrated acid nitric) extractions. These procedures extract more metals than those techniques used to analyze bioavailable metals. This explains why metal levels were low comparing to the regional reference. In some situations, the contamination in an area can be so significant that bioavailable metals quantities are much greater than the background. Pompêo et al. (2013) and Mariani and Pompêo (2008), for example, using the same technique described in this manuscript, found copper levels a hundredfold above background, in reservoirs sediments. In such way, the data in this research show that the contamination is not as expressive as observed in those other reservoirs.

For $\mathrm{Ni}$, the background value was higher than the ISQG. In such situations, the SQG should be replaced by the background value, unless a more suitable alternative is available (Chapman et al. 1999). The Ni levels measured here were therefore not indicative of toxic effects to the biota of the Paiva Castro reservoir.

In the case of $\mathrm{Cu}$, despite increases of this contaminant over time (Cardoso-Silva et al. 2016), due to the application of copper sulfate as an algicide, the present data did not indicate any bioavailability of the metal. From comparison of the metal levels in the Paiva Castro reservoir with those found for freshwaters ecosystem around the world and other reservoirs in the same hydrographic basin but with different levels of anthropogenic impacts (using the same extraction method), it could be observed that the metal concentrations in the Paiva Castro sediments did not exceed values found for the other systems (Table 5). Although there has been an expansion of urbanized areas along the Paiva Castro watershed, the sediments of this reservoir did not show any significant impacts.

Ecotoxicological tests performed in the region confirmed the low levels for metals, because they suggested the absence of toxic effects to biota in the sediments. Silva (2013) recorded acute toxicity in one of five samples collected in the rainy season (January, 2012), in the area where water extraction for public supply occurs. However, this toxicity may not necessarily be associated with metals because the author, using an almost total extraction for metal, did not found levels of metals above the background. This toxic potential found by Silva (2013) could also be caused by the presence of other compounds associated with increased anthropogenic activity in the Paiva Castro watershed. López-Doval et al. (2016) using data from the local environmental agency, CETESB (Companhia de Tecnologia de Saneamento Ambiental-Environmental Sanitation Technology Company), suggests how difficult is to relate the toxicity even when there is extensive survey of water and sediment, as performed by CETESB.

Sediment compartments in the Paiva Castro reservoir

The PCA component plots (Fig. 4a) suggested the existence of four compartments in the Paiva Castro reservoir.

Compartment I (positively correlated to axis 1 and 2) (Fig. 4a, b) was subdivided in Ia and Ib because although sampling sites 1 and 6 have chemical and physical similarities, they are located in different areas in Paiva Castro reservoir. Both areas had predominance of coarse sediments, which is typically deposited in high- 
Table 5 Metal concentrations in sediments from different freshwater ecosystems. Extractions were performed with $6 \mathrm{M} \mathrm{HCl}$, and values are expressed as milligrams per kilogram of dry sediment. The data are compared with empirical SQGs (ISQG and PEL)

\begin{tabular}{|c|c|c|c|c|c|c|}
\hline \multirow[b]{2}{*}{ Reservoirs } & \multicolumn{6}{|c|}{ Metais } \\
\hline & Cd & $\mathrm{Cr}$ & $\mathrm{Cu}$ & $\mathbf{N i}$ & $\mathbf{P b}$ & $\mathbf{Z n}$ \\
\hline Rio Grande (Billings)* & 10.1 & 55.4 & 1848.8 & 71.3 & 763.8 & 113.5 \\
\hline Guarapiranga $^{\dagger}$ & 10.7 & 59.6 & 1157.2 & $\mathbf{5 7 . 3}$ & - & 223.7 \\
\hline Promissão & 0.1 & 36.0 & 31.0 & 53.0 & 18.0 & 30.0 \\
\hline Bariri* & 0.2 & 34.0 & 47.0 & 63.0 & 36.0 & 59.0 \\
\hline Rasgão* & 2.4 & 142.0 & 224.0 & 86.0 & 104.0 & 858.0 \\
\hline Paiva Castro ${ }^{¥}$ & 0.3 & - & 3.9 & 1.4 & 13.5 & 12.9 \\
\hline $\begin{array}{l}\text { Oostvaarders Plassen }{ }^{1} \\
\text { (river in Netherlands) }\end{array}$ & 0.7 & - & 10.8 & 12.3 & 51.8 & 122.9 \\
\hline $\begin{array}{l}\text { Qionghie (Lake in } \\
\text { China) }^{2}\end{array}$ & 0.7 & - & 19.1 & 5.28 & 22.8 & 35.3 \\
\hline
\end{tabular}

"Mariani and Pompêo (2008); ${ }^{\dagger}$ Pompêo et al. (2013); ${ }^{\ddagger}$ Mozeto et al. (2006); ${ }^{\circledR}$ This work; ${ }^{1}$ Van Den Hoop'J (1997); ${ }^{2}$ Guo et al. 2015.

Below ISQG
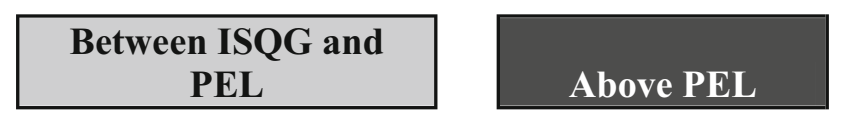

energy environments (He et al. 2011) and the highest levels of organic matter. These characteristics are typical of lotic areas, which is particularly the case of compartment Ia. In these areas, levels of organic matter presented carbon/nitrogen ratios indicating an allochthonous origin of this material (Cardoso-Silva et al. 2016), likely to have originated from the surrounding vegetation and also associated with effluents from a sewage treatment station located nearby in compartment Ia. Compartment Ib was characterized by a high water flow rate of around $33 \mathrm{~m}^{3} \mathrm{~s}^{-1}$, resulting from the water supply system which would explain the predominance of coarse sediments in the area.

Compartment II (positively correlated to axis 1 and negatively to axis 2) (Fig. 4a, b) was in a region defined as a transitional zone, according to the classical model of Thorton (1990). This area was indicated by the $\mathrm{E}_{\mathrm{H}}$ variable and showed the highest concentrations of $\mathrm{Mn}$ and $\mathrm{Cd}$ along the reservoir, an area potentially threatened by contamination with $\mathrm{Cd}$. The deepest reservoir region, with the predominance of clay and the highest levels of $\mathrm{Cu}$ and $\mathrm{Ni}$, the limnic zone, was categorized as Compartment III (Fig. 4b) and was negatively correlated to axis 1 (Fig. 4a). Although higher levels of $\mathrm{Ni}$ and $\mathrm{Cu}$ were found in the limnic area (Fig. 4a), no potential toxicity was identified. In the compartment where water extraction for public supply occurred, no values above the ISQG were found, and no toxicity was identified in the toxicological tests, indicating that the sediment conditions were suitable for the biota, in terms of the contaminants analyzed.

\section{Conclusions and recommendations}

Although previous research has identified high levels of copper in the sediments of the Paiva Castro reservoir, the present data revealed no bioavailability of the contaminants evaluated. This was supported by the toxicity tests, which indicated that the sediments provided suitable conditions for the aquatic organisms evaluated. The analyses also revealed that throughout the reservoir, sulfides were not the main metal binding phase. The sediments had low levels of organic matter, and oxic conditions were identified in at least one location, providing suitable conditions for the action of other complexing phases, such as clays and $\mathrm{Mn}$ oxyhydroxides, which were therefore mainly responsible for retention of the metals in the sediments. The compartmentalization of the reservoir sediments, revealed by the use of PCA, indicated that the upstream reservoir area was potentially threatened by 
contamination with $\mathrm{Cd}$. It is necessary that public policies continue to be developed and are effectively enforced by the government, in order to maintain the good quality of the Paiva Castro reservoir sediment.

Acknowledgments We are grateful to the Ecology Department of the Institute of Biosciences, University of São Paulo. Financial support for this work has been provided by FAPESP (Fundação de Amparo à Pesquisa do Estado de São Paulo), grant 470443/20081; scholarships were provided by CAPES (Coordenação de Aperfeiçoamento de Pessoal de Nível Superior) for Sheila Cardoso-Sillva, Daniel C.V.R. Silva, and Fernanda Lage and by CNPq (Conselho Nacional de Desenvolvimento Científico e Tecnológico) for Sheila Cardoso-Silva.

\section{Compliance with ethical standards}

Conflict of interest The authors declare that they have no competing interests.

Informed consent Informed consent was obtained from all authors involved in this research.

\section{References}

ABNT. (2007). Ecotoxicologia aquática- preservação e preparo de amostras. NBR 15469. Rio de Janeiro: ABNT.

ABNT. (2009). Água-Ensaios de toxicidade com Daphnia similis Claus, 1876 (Crustácea, Cladocera) Norma NBR 12713 (p. 23). Rio de Janeiro: ABNT.

Allaby M. (2008). Oxford dictionary of earth sciences, 3rd ed (p. 418). Oxford: Oxford University Press.

Allen, H. E., Boothman, W., Di Toro, D. M., \& Mahony, J. D. (1991). Determination of acid volatile sulfide and selected simultaneously extractable metals in sediment. EPA 821-R91-100. Washington: USEPA, Office of Water, Office of Science and Technology, Health and Ecological Criteria.

Allen, H. E., Fu, G., \& Deng, B. (1993). Analysis of acid-volatile sulfide (AVS) and simultaneously extracted metals (SEM) for the estimation of potential toxicity in aquatic sediments. Environ Toxicol Chem, 12, 1441-1453.

Ambühl, H., \& Bührer, H. (1975). Technik der Entnahme ungestörter Grossproblen von Seesedimenten: Ein verbessertes Boohrlot. Schweizerische Zeitschrift Fur Hydrologie-Swiss J Hydrol, 37, 175-186.

Araújo, R.P.A., Botta-Paschoal, C.M.R., Silvério, P.F., Almeida, F.V. Rodrigues, P. F., Umbuzeiro, G.A., Jardim, W.F. \&. Mozeto, A. A. (2006a). Application of toxicity identification evaluation to sediment in a Highly contaminated water reservoir in southeastern Brazil. Environmental Toxicology and Chemistry, 25 (2), 581-588.

Araújo, R.P.A., Shimizu, G.Y., Bohrer, M.B.C., Jardim, W.( 2006b). In: Zagatto, P.A. \& Bertoletti, E., eds,. Ecotoxicologia aquática: Princípios e aplicações. (p.464). São Carlos: RiMa.
Bartlett, R.J. (1999). Characterising soil redox potential. In: Sparks, D.L. (Ed.), Soil Physical Chemistry (pp. 371-389). Florida: CRC Press Boca Raton.

Beghelli, F.G.S.; Pompêo, M.L.M.; Rosa, A.H.; Moschini-Carlos, V. (2016). Effects of copper in sediments on benthic macroinvertebrate communities in tropical reservoirs. Limnetica. (accepted for publication)

Berner, R. A. (1981). A new geochemical classification of sedimentary environments. J Sediment Petrol, 51(2), 359-365.

Bizarro, V. G., Meurer, E. J., \& Tatsch, F. R. P. (2008). Teor de cádmio em fertilizantes fosfatados comercializados no Brasil. Ciência Rural, 38(1), 247-250.

Campana, O., Rodríguez, A., \& Blasco, J. (2009). Identification of a potential toxic hot spot associated with AVS spatial and seasonal variation. Arch EnvironContaination Toxicol, 56, 416-425.

Cardoso-Silva, S., Ferreira, P. A. L., Moschini-Carlos, V., Figueira, R. C. L., \& Pompeo, M. L. M. (2016). Temporal and spatial accumulation of heavy metals in the sediments at Paiva Castro Reservoir (São Paulo, Brazil). Environmental Earth Sciences, 75, 9.

CCME, Canadian Council of Ministers of the Environment. (1999). Protocol for the derivation of Canadian Sediment quality guidelines for the protection of aquatic life- CCME EPC-98E (p. 35). Ottawa: Environment Canada, Guideline Division, Technical Secretariat of the CCME Task Group on Water Quality Guidelines.

Chapman, P. M., Wang, F., Adams, W. J., \& Green, A. (1999). Appropriate applications of sediment quality values for metals and metalloids. Environ Sci Technol, 33(22), 39373941.

De Jonge, M., Dreesen, F., Paepe, J., Blust, R., \& Bervoets, L. (2009). Do acid volatile sulfides (AVS) influence the accumulation of sediment-bound metals to benthic invertebrates under natural field conditions? Environ Sci Technol, 43, 4510-4516.

De Jonge, M., Teuchies, J., Meire, P., Blust, R., \& Bervoets, L. (2012a). The impact of increased oxygen conditions on metal contaminated sediments part I: effects on redox status, sediment geochemistry and metal bioavailability. Water Res, 46, 2205-2214.

De Jonge, M., Teuchies, J., Meire, P., Blust, R. \& Bervoets, L. (2012b). The impact of increased oxygen conditions on metal contaminated sediments part II: effects on metal accumulation and toxicity in aquatic invertebrates. Water research, 46, 3387-3397

Di Toro, D. M., Mahony, J. D., Hansen, D. J., Scott, K. J., Hicks, M. B., Mayr, S. M., \& Redmon, M. S. (1990). Toxicity of cadmium in sediments: the role of acid volatile sulfide. Environ Toxicol Chem, 9, 1487-1502.

Di Toro, D. M., Zarba, C. S., Hansen, D. J., Berry, W. J., Swartz, R. C., Cowan, C. E., Pavlou, S. P., Allen, H. E., Thomas, N. A., \& Paquin, P. R. (1991). Technical basis for establishing sediment quality criteria for nonionic organic chemicals using equilibrium partitioning. Environ Toxicol Chem, 10, 1541-1583.

Fang, T. L., \& Zhang, G. (2005). Acid volatile sulfide and simultaneously extracted metals in the sediment cores of the Pearl River Estuary, South China. Ecotoxicol Environ Saf, 61, 420-431. 
Fonseca, A. C. (1997). Avaliação da qualidade da água na Bacia do Rio Piracicaba/SP através de toxicidade com invertebrados. São Carlos: Tese de Doutorado.

Förstner, U., \& Wittmann, G. T. W. (1981). Metal pollution in the aquatic environment (p. 486). New York: Springer-Verlag.

Garcia, C. A. B., Passos, E. A., \& Alves, J. P. H. (2011). Assessment of trace metals pollution in estuarine sediments using SEM-AVS and ERM-ERL predictions. Environ Monit Assess, 181, 385-397.

Giatti, L. L. (2000). Reservatório Paiva Castro- Mairiporã- SPAvaliação da qualidade da água sobre alguns parâmetros físicos, químicos e biológicos (1987-1998) (p. 87). São Paulo: FSP, USP.

Griethuysen, C. V., Lange, H. J. D., Van Den Heuij, M., Bies, S. C. D., Gillissen, F., \& Koelmans, A. A. (2006). Temporal dynamics of AVS and SEM in sediment of shallow freshwater floodplain lakes. Appl Geochem, 21, 632-642.

Hammer, Ø., Harper, D. A. T., \& Ryan, P. D. (2001). PAST: paleontological statistics software package for education and data analysis. Palaeontol Electro, 4(1), 9.

He, J., Lu, C., Fan, Q., Xue, H., \& Bao, J. (2011). Distribution of AVS-SEM, transformation mechanism and risk assessment of heavy metals in the Nanhai Lake in China. Environ Earth Sci, 64, 2025-2037.

Hübner, R., Astin, K. B., \& Herbert, J. H. (2009). Comparison of sediment quality guidelines (SQGs) for the assessment of metal contamination in marine and estuarine environments. J Environ Monit, 11, 713-722.

Huerta-Diaz, M. A., Carlgnan, R., \& Tessier, A. (1993). Measurement of trace metals associated with acid volatile sulfides and pyrite in organic freshwater sediments. Environ Sci Tech, 27, 2367-2372.

Jacob, D. L., Yellick, A. H., Kissoon, L. T. T., Asgary, A., Wijeyaratne, D. N., Saini-Eidukat, B., \& Otte, M. L. (2013). Cadmium and associated metals in soils and sediments of wetlands across the Northern Plains, USA. Environ Pollut, 178, 211-219.

Lee, J. S., Byeong-Gweon, L., Luoma, S. N., Choi, H. J., Koh, C., \& Brown, C. L. (2000). Influence of acid volatile sulfides and metal concentrations on metal partitioning in contaminated sediments. Environ Sci Tech, 34, 4511-4516.

Legendre, P. \& Legendre, L. (1998). Numerical Ecology (p. 853). Amsterdam: Elsevier Science.

López-Doval, J.; Meirelles; Cardoso-Silva, S.; Moschini-Carlos, V.; Pompeo, M. L. M. (2016). Ecological and toxicological responses in a multistressor scenario: are monitoring programs showing the stressors or just showing stress? A case study in Brazil. Science of the Total Environment, 540, 466476.

López, P., Dolz, J., Arbat, M., \& Armengol, J. (2012). Physical and chemical characterisation of superficial sediment of the Ribarroja Reservoir (River Ebro, NE Spain). Limnetica, 31, 327-340.

Luoma, S. N., \& Rainbow, P. S. (2008). Metal Contamination in Aquatic Environments: Science and Lateral Management (p. 573). Cambridge: Cambridge University.

Mariani, C. F., \& Pompêo, M. L. M. (2008). Potentially bioavailability metals in sediment from a tropical polymictic environment Rio Grande Reservoir, Brazil. J Soils Sediments, 8, 284-288.
Meguro, M. (2000). Métodos em Ecologia (p. 117). São Paulo: Apostila de Metodologias para a disciplina BIE - 321 Ecologia Vegetal - Instituto de Biociências, USP.

Mortvedt, J. J. (1996). Heavy metal contaminants in inorganic and organic fertilizers. Fertilizer Res, 43, 55-61.

Mozeto, A. A., Umbuzeiro, G. A., Araújo, R. P. A., \& Jardim, W. F. (2006). Esquema de Avaliação Integrada e Hierárquica da Qualidade de Sedimentos (AIHQS). In A. A. Mozeto, G. A. Umbuzeiro, \& W. F. Jardim (Eds.), Métodos de coleta, análises físico-químicas e ensaios biológicos e ecotoxicológicos de sedimentos de água doce (pp. 195221). São Carlos: Cubo.

Nascimento, M. R. L., \& Mozeto, A. (2008). Reference values for metals and metalloids concentration in botton sediments of Tietê river basin, soutjeast of Brasil. Soil Sediment Contam Int J, 17(3), 269-278.

Nizoli, E., \& Luiz-Silva, W. (2012). Seasonal AVS-SEM relationship in sediments and potential bioavailability of metals in industrialized estuary, southeastern Brazil. Environ Geochem Health, 34(2), 263-72.

Piper, C. S. (1947). Soil and Plant Analysis: Laboratory Manual of Methods for the Examination of Soils and the Determination of the Inorganic Constituents of Plants. New York: Interscience publishers.

Pompêo, M. L. M., Padial, P. R., Mariani, C. F., Cardoso-Silva, S., Moschini-Carlos, V., Silva, D. C. V. R., Paiva, T. C. B., \& Brandimarte, A. L. (2013). Biodisponibilidade de metais no sedimento de um reservatório tropical urbano (reservatório Guarapiranga - São Paulo (SP), Brasil): Há toxicidade potencial e heterogeneidade espacial? Geochim Bras, 27(2), 104-119.

Prica, M., Dalmacija, B., Rončević, S., Krčmar, D., \& Bečelić, M. (2008). A comparison of sediment quality results with acid volatile sulfide (AVS) and simultaneously extracted metals (SEM) ratio in Vojvodina (Serbia) sediments. Sci Total Environ, 389, 235-244.

Prica, M., Dalmacija, B., Dalmacija, M., Agbaba, J., Krcmar, D., Trickovic, J., \& Karlovic, E. (2010). Changes in metal availability during sediment oxidation and the correlation with the immobilization potential. Ecotoxicol Environ Saf, 73, 13701377.

Silva, D. C. V. R. (2013). Toxicidade potencial da água e sedimento de reservatórios da região metropolitana de São Paulo (represas Billings, Guarapiranga e Paiva Castro). 2013. Master thesis. São Paulo: Universidade de São Paulo.

Silva, E. A. S. (2002). Eutrofização no Reservatório Paiva Castro do sistema Cantareira na Região Metropolitana de São Paulo (1987-1997) (p. 135). São Paulo: FSP- USP.

Silvério, P. F., Fonseca, A. L., Botta-Paschoal, C. M. R., \& Mozeto, A. A. (2005). Release, bioavailability and toxicity of metals in lacustrine sediments: a case study of reservoirs and lakes in Southeast Brazil. Aquat EcosystHealth Manag, 8, 313-322.

Simpson, S. L., Ward, D., Stroma, D., \& Jolley, D. F. (2012). Oxidation of acid-volatile sulfide in surface sediments increases the release and toxicity of copper to the benthic amphipod Melita plumulosa. Chemosphere, 88, 953-961.

Thorton, K. W. (1990). Perspectives on reservoir limnology. In: Thorton K.W., Kimmel B.L., Payne F.E. (Eds.), Reservoir limnology: ecological perspectives (pp 1-13). New York: Wiley. 
US EPA, \& United States Environmental Protection Agency. (2005). Procedure for the derivation of Equilibrium Partitioning Sediment Benchmarks (ESBs) for the protection of benthic organisms: metal mixtures (cadmium, cooper, lead, nickel, silver and zinc) (p. 121). Washington: Office of Research and Development. EPA-600-R-02-011.

Velimirović, B., Prica, M. D., Dalmacija, B. D., Rončević, S. D., Dalmacija, M. B., Bečelić, M. D., \& Tričković, J. S. (2011). Characterisation, availability, and risk assessment of the metals in sediment after aging milica. Water Air Soil Pollut, 214, 219-229.

Vymazal, J. \& Švehla, J. (2013). Iron and manganese in sediments of constructed wetlands with horizontal subsurface flow treating municipal sewage. Ecological Engineering, 50, 60-75.
Whately, M., \& Cunha, P. M. (2007). Cantareira 2006: Um olhar sobre o maior manancial de água da Região Metropolitana de São Paulo- Resultados do Diagnóstico Socioambiental Participativo do Sistema Cantareira (p. 68). São Paulo: Instituto Sócio Ambiental.

Yin, H., \& Fan, C. (2011). Dynamics of reactive sulfide and its control on metal bioavailability and toxicity in metal-polluted sediments from Lake Taihu, China. Arch Environ Containation Toxicol, 60, 565-575.

Younis, A. M., El-Zokm, G. M., \& Okbah, M. A. (2014). Spatial variation of acid-volatile sulfide and simultaneously extracted metals in Egyptian Mediterranean Sea lagoon sediments. Environ Monit Assess, 186, 3567-3579. 